\title{
The insoluble conflict of the racial divide - white and black - in Nella Larsen's novels Passing and Quicksand
}

\section{O conflito insolúvel da divisão racial - branco e preto - nos romances de Nella Larsen Passing e Quicksand}

Doutora em Letras com ênfase em Literatura Inglesa. Atua como bolsista do curso de linguas NELE da UFRGS. Autora de Literatura Afro-Americana: uma leitura de maes negras" capitulo do livro $A$ Música das Esferas: Conexões entre Literatura, Mitologia e Elming, publicado em
ABSTRACT: This work presents a reading of the novels Quicksand and Passing in the classroom, with a focus on the question of race and ensuing conflicts of 'passing. These novels were published respectively in 1928 and 1929 by African-American writer Nella Larsen during the cultural and aesthetic movement called the Harlem Renaissance, a movement whose heyday in the 20's in the last century brought about the uplifting of racial consciousness and the emergence of modern African-American literature. In the decade, the experience of 'passing' constituted one of the privileged topics in several novels by Afro-American writers. My analysis draws supports from Thadious M. Davis, Elaine K. Ginsber and Martha J. Cutter in relation to racial and identity conflicts. In the interweaving of psychological, cultural and literary elements, my reading shows how these novels dramatize the insoluble conflict of the racial divide - white and black - that underlines the characters' struggles and difficulties when facing the void in belongingness that attends the experience of 'passing'. This research aim at approaching and discussing in the classroom the cultural aspect of racial conflicts which is always up to date and relevant.

KEYwoRDS: African-American literature; Passing; Race.

RESUMO: Este trabalho apresenta uma leitura dos romances Quicksand e Passing na sala de aula focando nas questões de raça e conflitos de passing Esses romances foram publicados, respectivamente em 1928 e 1929, pela escritora Afro-americana Nella Larsen durante o movimento cultural e estético chamado Harlem Renaissance, um movimento cujo apogeu aconteceu nos anos 20 do século passado provocando a elevação da consciência racial e a emergência da literatura Afro-americana. Nesta década, a experiência de passing constituía um dos temas privilegiados em alguns romances de escritores Afro-americanos. Minha análise se sustenta na obra de Thadious M. Davis, Elaine K. Ginsber e Martha J. Cutter em relação a conflitos raciais e identitários. No entrelaçamento de elementos psicológicos e culturais, minha leitura mostra como esses romances dramatizam o conflito insolúvel da raça dividida - branca e negra - que destaca as lutas e dificuldades das personagens quando se deparam com o vazio do pertencimento do qual trata a experiência de passing. Esta pesquisa tem como objetivo abordar e discutir em sala de aula o aspecto cultural de conflitos raciais que é algo sempre atual e relevante.

Palavras-chave: Literatura Afro-americana; Passing; Raça. 
My old man died in a fine big house. My ma died in a shack. I wonder where I'm gonna die. Being neither white nor black? (LANGSTON HUGHES, "Cross")

\section{Introduction}

W hy is it important to bring to class novels approaching delicate and complex issues like racial conflicts? To answer this question, first of all, I draw support from the words professor and researcher of Critical Discourse Analysis, Teun A. van Dijk, used when he asserted at the opening lecture at DUO VII (Dialogue Under Occupation) ${ }^{2}$ that "prejudice and racism are not innate. You learn to be racist" (DIJK, 2015). By taking this assertion into account, it is possible to think that, if racism can be learned, the other way around is also possible. As such, anyone can learn to be anti-racist too.

Furthermore, ideas and beliefs are spread through culture in order to support the hegemony of a society. Culture is defined as a system of normative beliefs that reinforces some social institutions such as race. The word race, for example, like many other social conventions, has undergone some transformations along history. Initially, it was a product of European imperialism and colonization. According to Stuart Hall's ideas in Representation Cultural Representations and Signifying Practices "the images of racial difference" underwent some changes along history. At first, Africa was seen by the European as something positive. However, as time passes, this image suffers some modifications. As Hall asserts, changing from a positive to a negative image "Africans were declared to be the descendants

\footnotetext{
${ }_{1}$ This poem is available at <http://www.poemhunter.com/poem/cross/>, accessed on April 15th, 2015 2 This event happened at PUCRS from October 28th to October 30th, 2015.
}

of Ham, cursed in The Bible to be in perpetuity 'a servant of servants unto this brethren'"(HALL, 1997, p. 239). Hall goes further saying that Africans were also "identified with Nature, they symbolized 'the primitive' in contrast with the 'civilized world"' (HALL, 1997, p. 239). For this reason, he argues that the intention "behind naturalization is simple. If differences between black and white people are 'cultural', then they are open to modification, and change. But if they are 'natural' - as the slave-holders believed - then they are beyond history, permanent and fixed" (HALL, 1997, p. 245). Nowadays, such view changed and Stuart Hall and other scholars understand that race is a human invention, a social construct used in order to manage difference ${ }^{3}$. The anthropologist Franz Boas, for instance, argues that ideas of race are culturally constructed and that skin color indicates little about innate differences. However, during last century, it was spread as a natural truth ${ }^{4}$, used to reinforce black exploitation.

As a teacher, I understand that Dijk's and Hall's ideas mentioned above should be discussed in class. Considering that one of the most adequate places to raise awareness and discuss polemic and delicate topics is the classroom. Within a classroom environment, delicate issues like racism and prejudice can be held with care and acuity. It is an appropriate environment to encourage discussions, raise racial consciousness and promote mutual respect among students. Actually, taking into account Sociologist Paulo Freire's words "no one can be in the world, with the world and with others neutrally" (FREIRE, 1996, p. 86). This way, teachers should take advantage

3 This source of information is available at http://www.columbia. edu/cu/anthropology/about/main/

4 one/boas.html and was accessed on November 8th, 2015.
According to David Pilgrim "many Christian ministers and theologians taught that Whites were the According to David Pilgrim "many Christian ministers and theologians taught that Whites were the Chosen people, Blacks were cursed to be servants, and God supported racial segregation. Craniologists eugenicists, phrenologists, and social Darwinists, at every educational level, buttressed the belief that
Blacks were innately intellectually and culturally inferior to whites." This source of information is Blacks were innately intellectually and culturally inferior to whites." This source of information is
available at http://www.ferris.edu/jimcrow/what.htm.

tém pode estar no mundo, com o mundo e com os outros de forma neutra" (FREIRE, 1998, p. 86) 
of their position as educators in order to enhance knowledge, consciousness and critical thinking. For this reason, this work proposes a reading and a discussion of an African-American novelist named Nella Larsen. Her social context and novels can be seen as a document of African-American society of twentieth century. And this is a very rich material to bring to class in order to illustrated racial conflicts. To do so, firstly, I am going to introduce Nella Larsen's social context, secondly, I am going to present pieces of her biography and, thirdly, her novels will be discussed.

\section{Larsen's Social Context}

In order to understand better the America in which Larsen grew up and lived, it is important to go a little back in time. After the Emancipation Proclamation in 1863 more than 50,000 African-American people were abandoned to their fate. They got freedom, however, it had a price to pay, they were segregated and morally depreciated. According to Jim Crow codes of law 6 , African-American people were "separate but equal". Besides being segregated, they underwent moral and physical abuse. As such, they were represented as stereotyped characters in movies, and advertisements, as well as ridiculed in minstrel's shows. And if, for any reason, they disobeyed those codes of law, they would suffer physical abuse or ended up lynched. Due to this hostile atmosphere, and with the outbreak of the great depression after World War I, a large number of African-Americans decided to migrate from South to North aiming at better life conditions. The migration from

6 "The segregation and disenfranchisement laws known as "Jim Crow" represented a formal, codified system of racial apartheid that dominated the American South for three quarters of a century beginning in the $1890 \mathrm{~s}$. The laws affected almost every aspect of daily life, mating a century beginning parks, libraries, drinking fountains, restrooms, buses, trains, and restaurants. "Whites Only" and "Colored" signs, drenking fountains, restroons, buses, trains, and restaurants. "Whites Only" and org/wgbh/americanexperience/freedomriders/issues/jim-crow-laws>, accessed on May 3rd, 2016. countryside to town gave the African-American the opportunity to acquiring experience and earning more money. Also, the geographical change raised in them an impression of economic freedom. However, it was just an illusion, because they quickly realized that geographic mobility did not erase prejudice. African-Americans were still considered as inferior in the North as they were in the South. And the riots and lynching that swept the North in 1919 helped increase their disillusionment with American democracy.

Actually, the early twentieth century went through many political troubles such as the World War I, the Russian Revolution, and the emerging of Fascism in Italy and Nazism in Germany that lately culminated in World War II. Such conflicts in politics affected the world of arts too. The artists could not be impartial before such changes; they felt that it was a time of breaking off old conventions. Within this hostile context, artists started to reflect about old truths, everything that was accepted as the norm, in politics, in religion, and even in art was reevaluated. The African-American artists and scholars took advantage of that moment of reflection and reevaluation to reinterpret their own lives and culture. Thus, they decided to create their own artistically, aesthetic and cultural movement named The Harlem Renaissance. As Nathan Irvin Huggins pointed out:

Much of the racial problem of the United States was due to the ignorance of whites of the true character of blacks, and ignorance of blacks of their own true qualities as people. The production of art and literature would serve to lift this cloud of ignorance by demonstrating to the white world that blacks could achieve on the highest level, measured by Euro-American standards (HUGGINS, 1995, p. 279).

What we had with the Harlem Renaissance was the emergence of the questions of voice fostered by a black consciousness. African-American writers started to produce a kind of literature that expressed through artistic forms their anxieties, desires, and uncertainties. According to Robert 
A. Bone "the Negro Renaissance was essentially a period of self-discovery, marked by a sudden growth of interest in things Negro" (BONE, 1970, p. 62), this way, it is possible to say that this movement was a turning point for African-American people in many aspects such as artistically, cultural and social.

Several men took part in the Harlem Renaissance, however, just few women were involved in it. Those women found some obstacles that prevent them from sources of patronage, and faced some difficulties in getting their work published. However, some surpassed the adversities and managed to get their novels printed and published like Nella Larsen, Jessie Fauset and Zora Neale Hurston to mention some. These writers overcame the difficulties and exposed their anguishes through their heroines. The main theme of those writers was black women role in American society of the beginning of the twentieth century. Those aforementioned authors were very important to the Harlem Renaissance; however the focus of this work is in Nella Larsen.

\subsection{Nella Larsen}

Nella Larsen was born in a mixed-race family, her mother Mary Hanson Walker was a white woman of Danish origin, and her father Peter Walker was a black man from West Indies. When Larsen was only two-years-old her father disappeared and shortly afterwards, her mother married a white man and Larsen became the only black member of her family. Larsen's mixedrace family's experience could be of great contribution to the understanding the American society of the late nineteenth and early twentieth century. Interracial families were illegal in some places of the United States, therefore, Larsen lived a childhood of dislocation, her family had to move in order to escape prejudice and illegal issues that a black family member could cause to the other members. Such impasse resulted in a prematurely removal of
Larsen from her family. From very early, in her life, Larsen realized that she did not have anyone to support her, thus, she should be independent and self-sufficient in order to survive.

Larsen's mother, Mary, saw in education as a way of helping improve her daughter's chances of survival in a segregated society. Mary registered Larsen in Fisk University, an institution for teacher's education in Nashville. Such experience was very important for Larsen, a girl who used to live surrounded only by whites, went to a place where there were no white students. That was a significant change in her life as George Hutchinson observed "it was a time for her to find her place in the Negro World to which her family would never belong" (HUTCHINSON, 2006, p. 52). A similar experience can be exemplified by Larsen's protagonist, Helga Crane, in Quicksand, when she first went to a school for black students, and said, "she discovered that because one was dark one was not necessarily loathsome, and could, therefore, consider oneself without repulsion" (LARSEN, 2001, p.57). After a year in Fisk, Larsen was expelled. Then, she went to Copenhagen to spend some time with her relatives. This experience last for three years, thus, she returned to the USA and started working as a nurse in hospital. There she met an AfricanAmerican doctor who later on became her husband. After getting married and moving to Harlem, Larsen's life and career changed.

Influenced by the intellectual vicinity, she started to work as a librarian, and the proximity with books provided Larsen with familiarity with the literary artistic devices to her further career as a writer. Larsen's first short story, "The wrong Man" (1926) was published in a magazine called Young's Realistic Stories Magazine. In this story she dealt with themes of sexuality and psychological aspects, something that would be developed in her later fiction. Three months later, Larsen published in the same magazine her second short story entitled "Freedom". Her next works deal with questions of racial issues and identity. Two years after her first venture writing a short 
story, Nella Larsen published her first novel Quicksand, and a year after it, she published her last novel Passing.

Larsen's second novel offers an intriguing and enigmatic title, Passing. Many readers who go through this text may wonder what this title means. A look up in the Oxford Dictionary might give these definitions "that something is ending or that somebody is dying", however, such definitions are not sufficient to decipher this enigmatic title. As we start reading Passing, the protagonists Clare Kendry Bellew and Irene Westover Redfield bring out their understanding of 'passing'. Clare sees it as "a frightfully easy thing to do" (LARSEN, 2003, p. 25). On the other hand, Irene calls it a "hazardous business" (LARSEN, 2003, p. 24). Since this novels ends up with the death of one of the protagonists, readers might imagine that the title has to do with it, with this death; however, this interpretation is too simplistic, a close reading of some researchers about 'passing' might be helpful to find out a reasonable interpretation to this word.

As a matter of fact, the word 'passing' as well as the title of the novel, carry many interpretations, for instance, as Elaine K. Ginsberg observes in Passing and Fictions of Identity,

passing in American history associates it with the discourse of racial difference and especially with the assumption of a fraudulent 'white' (...) 'such an individual crossed or passed through a racial line or boundary - indeed trespassed - to assume a new identity and accessing the privileges and status of the other (GINSBERG, 1996, p. 3).

Thadious M. Davis presents in the introductory text of the novel that 'passing' is "the movement of a person who is legally or socially designed black into a white category or white social identity" (DAVIS, 2003, p. viii). Accordingly, it is possible to say that 'passing' may be a desire that some individuals have of being white, as Martha J. Cutter argues 'passing' "is a strategy to be a person", of escaping boundaries and prejudice, desire for adherence to a culture that would provide privileges. Actually she states that "only when 'passing' becomes a subversive strategy for avoiding the enclosures of a racist, classist, and sexist society does it become truly liberating" (CUTTER, 1996, p. 75). Another important aspect to be enlightened is the metaphor of the divided self in terms of belongingness - white or black, the metaphor names one thing with the name of another thing on the assumption of a relation of similarity in comparison between the two things. For Cutter, "'passing' becomes the ultimate mechanism for creating a text that refuses to be contained, consumed, or reduced to a unitary meaning" (CUTTER, 1996, p. 76).

As it is possible to see, to be a black person in the United States, especially in a time where prejudice seems to be the rule might not be an easy thing. For someone of a mixed-race origin sometimes it was even worse, because they were not comfortable among both communities: the white and black. Therefore, if possible, the best option was to disguise one of the ancestries. When an individual assumed his or her African ancestry this person ran the risk of suffering some consequences, such as being excluded, threatened or living in the border of American society. Some people, under extreme circumstances, chose to hide their heritage and passed for something that they were not in order to obtain some privileges, rights, and opportunities denied to them and often given to the dominant group. 'Passing', a useful practice among black people, in the United States of the $20^{\text {th }}$ century, is the main topic of Nella Larsen's two only novels Quicksand and Passing. Larsen's work becomes extremely relevant if we want to analyze this kind of practice used by people who seek for a place, an identity, and who at the same time have to endure a differentiated treatment due to their race or gender, even among other blacks and descendant of blacks. 


\subsection{Larsen's novels: Quicksand and Passing}

In 1928, Larsen published her first novel Quicksand. This novel examines the life of an intelligent and solitary girl, Helga Craine, who, grappling with her lack of adaptation as a black woman and with her bitterness towards whites, roams from place to place searching for a suitable identity. For Helga, the huge problem of her life is race. In fact, the tragedy of Helga lies in her inability to recognize her real problems that are more emotional than racial ones. And that misconception led her to a bad end. Her endless search ended up entrapping her in an undesirable marriage and motherhood. Some aspects of Helga's life story are similar to Larsen's biography, both were originally from a mixed-race family, had a childhood among white people, and Danish relatives.

The epigraph above presents an excerpt from Langston Hughes's poem Cross, which Larsen presents in Quicksand. Such excerpt summarizes the great difficulty a mixed-race individual faces in order to identify him or herself to a single culture, a single race and to forge a proper sense of identity. This quest for one's identity is a common issue in AfricanAmerican literature, as well as it must have been in Larsen's segregated society, especially for those who have been in touch with both cultures (black $^{7}$ and white) and must have felt that they do not belong to any of them. This sense of being dislodged, or displaced, approached in Hughes's poem, takes part in Nella Larsen's literary works as well as in her own life story. Indeed, Thadious M. Davis claims that, "the forging of a racial identity was a general objective of the New Negro Renaissance, but for Larsen, the

\footnotetext{
Taking into account that throughout my reading of subjects relating to African-American culture and literature, I found a variation of words to refer to African-American people, in this work I decided not to privilege any of them. Thus, every time one of these options appeared, "black, Negro, African-American, or colored", they mean the same thing, African-American people.
}

validating of a personal identity, conjoining gender and race, was even more essential" (DAVIS, 1994, p. 242).

When it comes to social identity, Tajfel and Turner proposes that, "a person has no one, 'personal self', but rather several selves that correspond to widening circles of group membership. Different social contexts may trigger an individual to think, feel and act on basis of his personal, family or national "level of self"' (TAJFEL; TURNER, 1986). This way, in a broad sense social identity is not something fixed and unitary, yet something multiple. Equally, it is possible to assert that Cutter has a similar idea of Tajfel \& Turner about social identity, she also sees it as something multiple. Still she is dealing with the racial aspect, which is another aspect that comprises identity issues. In regards to a racial context, social identity turns into an even more complex and delicate issue as Larsen's novels show. The author Nella Larsen as mixed-race woman experienced the adversities of her time. And this experience reflects in her literary works and provides a discussion of how problematic identity formation to African-American individuals might have been. Throughout Larsen's works, especially in her novel Passing, one can witness the condition of black people in Harlem. The main characters of the novel, Clare and Irene, point out and deal with the practice of 'passing'.

In addition to it, in many ways literature functions as representative of a language, a people, a culture, a tradition. It is possible to say that this artistic creation contributes to the interpretation of our own world and own lives. In this sense, literary journeys undertaken in the act of reading stories makes possible an interpretation of our lives, ourselves, and of what we read and write. Actually, in literature, it is possible to identify images, emotions, allegories and descriptions of what may have happened in real life. Most of the time, the author's writing seems to speak to us, acting upon us and affecting our sense of self. Accordingly, Nella Larsen's fascinating character Clare Kendry has struck a chord with me, she is so intense that destabilize 
my sense of self. Right in the beginning of the story the narrator describes her as,

Catlike. Certainly that was the word which best described Clare Kendry, if any single word could describe her. Sometimes she was hard and apparently without feeling at all; sometimes she was affectionate and rashly impulsive. And there was about her an amazing soft malice, hidden well away until provoked. Then she was capable of scratching, and very effectively too. Or, driven to anger, she would fight with a ferocity and impetuousness that disregarded or forgot any danger; superior strength, numbers, or other unfavourable circumstances (LARSEN, 2003, p. 10-11).

As it is possible to see, Clare is compared to felines, the most inconstant and fascinating animals. It is impossible to be indifferent to cats either we hate them or love them. The same happens to Clare. In fact, as Martha J. Cutter observes, Clare is a kind of character that destabilizes not only the life of the characters in the story she is inserted in, but the reader's life too,

Clare's sliding significations within the text are meant to destabilize both other characters and reader's sense of identity. Through Clare, readers are deliberately invited to construct their own interpretations of the text and in so doing to see the problematic plural of Clare's identity and of identity in general (CUTTER, 1996, p. 84-85).

Clare's pursuit for an identity has to do with racial issues, a complex and complicated thematic. As I have mentioned before, in the United States of the late nineteenth and early twentieths century, many people were set aside to the margin because of their skin color, their African origin. Even so, Clare, is a woman who, despite of all the adversities that a racist and patriarchal society impose on her, defies her fate and struggles to find a place among her peers (the black community). I understand that her upshot was a tragic one; however, she demonstrates strength, courage and daringness throughout the course of her life. Clare's fate is cursed according to her religious aunts who believed black people should be subservient and work a lot because it is written in the Bible. Nevertheless, Clare did not accept that destiny as she exclaimed "I was determined to get away, to be a person and not a charity or a problem, or even a daughter of the indiscreet Ham ${ }^{8 "}$ (LARSEN, 2003, p. 26). In the novel, Clare challenges her destiny and changes from a subservient position to a comfortable and desirable position of a woman from the white bourgeoisie. She passed as a white woman and married a white racist man.

Actually, Larsen wrote two novels tackling the issue of the racial divide and identity. The quest for self, approached in Larsen's novels, has a close relation to 'passing'. For Cutter, passing turns identity into "a performance, a mask, a public persona", meaning that, the individual takes on a role according to a given situation and purpose. Davis sees passing as a way of escaping containment of discriminatory practices in order to access "constitutional rights enjoyed by the white majority" (DAVIS, 2003, p. ix). By passing as white, African-American people who had light skin could access to fundamental rights that were denied to them by law. If legally they were obliged to live apart from the white community because of a controversial law which segregated them, these individuals saw in passing as a way of disrupting this rule by disguising themselves as white and taking part of the white community. Initially, 'passing' referred to a fair-skinned person of African origin disguised as white. But at the end of the twentieth century, the meaning of passing acquired a wide scope, and turned into a common

8 "Sons and daughters of Ham": (Genesis 9:20-27). Literally, the Canaanites, the descendants of Ham one of the three sons of Noah, saved from God's destruction of a wicked world by flooding. Ham was punished for mocking his father's drunkenness and nakedness. Ham's punishment for disrespecting punished for mocking his father's drunkenness and nakedness. Ham's punishment for disrespecting his father fell upon his children who were cursed to become the slaves of his brothers' children; slave holders in the United States applied this Biblical account to Africans and used it as a justification for slavery. These words take part in the explanatory notes of Nella Larsen's novel Passing (DAVIS,
p. 117, 2003). 
usage. Although it had the same meaning as "masking" or "disguising", the usage has changed. People have been using this practice to disguise and mask many aspects of identity, such as class, ethnicity, religion, or sexuality (DAVIS, 2003). There are many different kinds of passing, there are people who pass for white, for rich, for heterosexual, to mention but a few. The underlying reason for this practice is the need to belong, to be part of a group who is accepted and has easier access to rights and benefits in society.

To shed light to these aforementioned issues, let us plunge into Larsen's fictional universe and see how her characters deal with those dilemmas. In her first novel Quicksand, for instance, Larsen portrays a heroine, Helga Craine, who searches throughout the story for what Cutter calls "a unitary sense of identity - a sense of identity structured around one role, a role that somehow corresponds to her "essential self"' (CUTTER, 1996, p. 83). However, this search leads this heroine to a dead end, to a psychological death. What Helga never realizes, according to Cutter, is "the fact that perhaps her identity itself is both plural and social and, therefore, that she can never achieve synthesis of self" (CUTTER, 1996, p. 83). Which means, Helga can never achieve a unitary racial identity, she can never play a unitary role in society, because identity is not unitary, it is plural. And Helga is both: black and white, mother and wife, woman and teacher, not one or other. In an attempt to find a suitable identity, a proper role in her society, a synthesis of self, Helga undergoes many trials. First, she passes for a committed teacher in Naxos, secondly, as a legitimate black woman (passing for black ${ }^{9}$ ) among black middle-class in Harlem, and thirdly, as an exotic woman in Denmark among her white relatives. Consequently, this heroine ends up entrapped in a marriage without love, because she does not understand that a fixed and

${ }_{9}^{9}$ It is important to say that African American community is also prejudiced about mixed race individuals. unitary identity does not exist. As Cutter asserts "to assume a single identity", or to play a single role in a society that sees identity as "a performance... a public persona is to ensure psychological suicide" (CUTTER, 1996, p. 76). Thus, it is exactly what happens to Helga. After five pregnancies, she cannot escape anymore, and she is condemned to remain in that marriage performing the role of a dedicated mother and submissive wife. By reading Helga's questions and dilemmas, it is impossible not to feel empathy for someone who is totally dislodged and confused trying to discover her real self.

Differently from Helga, in Quicksand, Clare, in Passing is a heroine who does not search for a single racial identity, in achieving a synthesis of self, or playing a single role in society. Instead, this heroine refuses containment. Her identity is multiple. She also undergoes many trials. She passes for white, a bourgeoisie woman, a dedicate mother, and a lovely wife; however, none of these roles seem to fit her and fulfill her wishes and desires. Irene, the second protagonist of Passing, echoes some characteristics of Helga: she pursues security and the maintenance of her marriage throughout the story. For her, security means to be a dedicated wife and mother within her black community. However, Clare's presence in the story destabilizes her sense of security and shed light on Irene's ideas of the impossibility of a secure life and a single racial identity. In Passing, Larsen goes further approaching these complex issues of self-discovery and identity formation. She puts together two different women who mirror each other, one destabilizing the life of the other. Passing portrays the universe of two beautiful middle class mulattoes, Clare and Irene, who pass for white, one permanently and the other one intermittently. Irene uses passing as a convenient trick, to enter some places where black people are not allowed. In the scene at the Drayton hotel, where she meets Clare after twelve years is an example of this. She even observes that, 
White people were so stupid about such things for all they usually asserted that they were able to tell; and by the most ridiculous means, finger-nails, palms of hands, shapes of ears, teeth, and other equally silly rot. They always took her for an Italian, a Spaniard, a Mexican, or a gipsy. Never, when she was alone, had they even remotely seemed to suspect that she was a Negro (LARSEN, p. 16, 2003).

Clare, on the other hand, leaves her past behind and passes permanently. Larsen's characters represent the black bourgeoisie of Harlem. Although all the adversities of that time, segregation, discrimination, lynching, black people manage to succeed. Irene's husband, for example, is a doctor. Larsen explored the universe of a middle class society in order to show that black people were capable of succeeding although the adversities they face, and they were not inferior as the mainstream American society insisted on stating.

As I have mentioned before, the term 'passing', turned nowadays into a common usage, it disguises and masks any aspect of identity, such as class, ethnicity, religion or sexuality, implying as well as unmasking or exposing of one viable construction of a cultural identity. In this sense, it is possible to say that, in a society in which appearances are worth more than essence, to show a real self might require courage, which is something that just few people are endowed with. Thus, it is convenient for an individual to pass for someone that follows the patterns of a determined framework in order to be accepted. Nevertheless, Larsen exposed in her novel the tragedy that 'passing' can bring about. Even if the characters might present a positive value associated to resistance, this experience also brings to the individual a feeling of void in terms of belongingness.

\section{Final Words}

Considering all the things that were presented in this work, it is possible to conclude that a research about racial issues continue to be up to date and relevant. A hundred and fifty two years have passed after the Emancipation Proclamation in The United States and a hundred and twenty seven years after Emancipation Proclamation in Brazil, but we still feel the consequences of those dark times of bondage. Many advances have happened since there, but it is necessary to improve even more. One of the worst consequences of that time is the prejudice against African descendent people. Although, we have some examples of successful people as the USA president Barak Obama, and ex-president of the Supremo Tribunal Federal in Brazil Joaquim Barbosa, most of black people still live in the borders of the society. Even though racial prejudice is a crime in Brazil, it continue to be a reality in our society, for instance, recently some famous black people such as artists, journalists and soccer players have undergone prejudice on the social networks and at stadiums.

In this sense, the reading of Larsen's work and biography prove to be a very rich material to be discussed in the classroom focusing on racial issues. The analysis of the United States, during the time of segregation and racial conflicts can be a good way of introducing this theme. Thus, the combination of a piece of art as literature and pieces of historical facts can raise awareness about the outcomes of racial conflicts. As a matter of fact, people from African origin continue to suffer racial prejudice either in North America as in Brazilian society. Still today, racism is a common practice. Unfortunately, people continue to be judged by the color of their skin and not "by the content of their character" as Martin Luther King once dreamt of (KING, 1963, p. 5). And by resuming the words of Dijk and Hall racism is a social convention made up by the dominant society in order to reinforce discrimination. Therefore, it is really important to continue thinking and talking about these complex issues in order to change this scenery for the better. 


\section{References}

BONE, Robert A. The Negro novel in America. New Haven and London: Yale University Press, 1970.

CUTTER, Martha J. Sliding significations: passing as a narrative and textual strategy in Nella Larsen's fiction. In: GINSBERG, Elaine K. Passing and the fictions of identity. Durham and London: Duke University Press, 1996.

DAVIS, Thadious M. Nella Larsen novelist of the Harlem Renaissance - A woman's life unveiled. Baton Rouge and London: Louisiana State University Press, 1994.

Introduction. In: LARSEN, Nella. Passing. New York: Penguin Books, 2003.

DU BOIS, William. E.B. The souls of black folk. New York: Signet Classic, 1995.

FREIRE, Paulo. Pedagogia da Autonomia: saberes necessários à prática educativa. São Paulo: Paz e Terra, 1998.

GINSBERG, Elaine K. Passing and the fictions of identity. Durham and London: Duke University Press, 1996.

HALL, Stuart. Representation cultural representations and signifying practices. London: SAGE publications, 1997.

HUGGINS, Nathan Irvin. Voices from the Harlem Renaissance. New York: Oxford University Press, 1995.

HUTCHINSON, George. In search of Nella Larsen a biography of the color line. Cambridge: The Belknap Press of Harvard University Press, 2006.

WEHMEIER, Sally. Oxford Advanced Learner's Dictionary of Current English. New York: Oxford University Press, 2007.

KING, Martin Luther. "I have a dream". Available at: <www.archives.gov/press/exhibits/ dream-speech.pdf>. Accessed on October 9th, 2015.

LARSON, Charles R. The complete fiction of Nella Larsen. New York: Anchor Books Edition, 2001.

LARSEN, Nella. Passing. New York: Penguin Books, 2003.

SCHOMBURG, Arthur A. The Negro digs up his past. In: HUGGINS, Nathan Irvin. Voices from the Harlem Renaissance. New York: Oxford University Press, 1995.
TAJFEL, H.; TURNER, J. C. The social identity theory of inter-group behavior. In: WORCHEL, S.; AUSTIN, L. W. (Eds.). Psychology of Intergroup Relations. Chicago: Nelson-Hall, 1986. VAN DIJK, Teun A. "Antirracismo e discurso político no Brasil". Auditório do Prédio 32, PUCRS, 2015. Conferência Inaugural.

Recebido em 09/11/2015.

Aceito em 28/04/2016. 